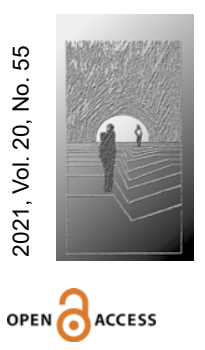

\title{
Potrzeba wsparcia poradniczego dla młodzieży z grup szczególnego ryzyka
}

\section{STRESZCZENIE}

CEL NAUKOWY: Celem podjętych rozważań jest zwrócenie uwagi na ryzyko wykluczenia edukacyjnego bądź bierności zawodowej młodych, którzy doświadczają negatywnych skutków sytuacji społecznej, spotęgowanej pandemią oraz zasygnalizowanie potrzeby zaprojektowania wsparcia poradniczego adresowanego do młodych przynależących do tzw. grup ryzyka.

PROBLEM I METODY BADAWCZE: Artykuł ma charakter przeglądowy. Analizując literaturę przedmiotu oraz doniesienia publicystyczne, autorka stara się zasygnalizować narastający problem przedwczesnego opuszczania oraz przerywania edukacji przez młodzież w czasie pandemii, a także jego związek z biernością zawodową, a nawet wykluczeniem społecznym młodych w przyszłości.

PROCES WYWODU: Artykuł rozpoczęto od nakreślenia pogarszającej się sytuacji młodych, szczególnie w kontekście rynku pracy, którą skorelowano ze zwiększonym ryzykiem bierności edukacyjno-zawodowej młodych oraz podkreślono potrzebę wsparcia poradniczego dla młodych zagrożonych wykluczeniem.

WYNIKI ANALIZY NAUKOWEJ: Przeprowadzona analiza wykazała, że okres pandemii istotnie zwiększył zapotrzebowanie na zindywidualizowane wsparcie poradnicze skoncentrowane na potrzebach młodzieży z grup szczególnego ryzyka, uwzględniające różne konteksty jej funkcjonowania.

WNIOSKI, INNOWACJE, REKOMENDACJE: Celem nowoczesnych interwencji w zakresie poradnictwa całożyciowego nie powinno być wyłącznie przygotowanie młodych do znalezienia pracy, zdobycia zawodu, uzupełnienia edukacji, ale także tworzenie warunków do rozwoju zasobów karierowych, które nie tylko przygotują do efektywnego funkcjonowania na rynku pracy, ale też przybliżą ich do pełnej, dojrzałej, odpowiedzialnej dorosłości.

\section{$\rightarrow$ SŁOWA KLUCZOWE: MŁODZIEŻ, WYKLUCZENIE EDUKACYJNE, WSPARCIE PORADNICZE, NEET}




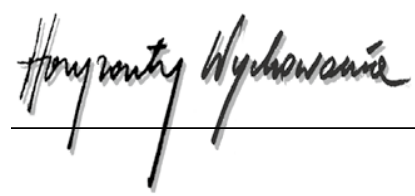

ABSTRACT

The Need for Counselling Support for Youth at Risk

RESEARCH OBJECTIVE: The aim of conducted considerations is to draw attention to the risk of educational exclusion or professional inactivity of young people who experience the negative effects of social situation, aggravated by the pandemic and to signal the need to design counselling support addressed to young people belonging to so-called risk groups.

THE RESEARCH PROBLEM AND METHODS: The article character of overview. Analyzing the literature on the subject and journalistic reports, the author tries to signal the growing problem of premature leaving and interrupting education by young people during the pandemic, as well as its connection with professional inactivity and even social exclusion of the young in the future.

THE PROCESS OF ARGUMENTATION: The article starts with outlining the deteriorating situation of the youth, particularly in the context of their current situation on the labour market- This situation was correlated with an increased risk of educational and professional inactivity of the youth and emphasized the need for counselling support for them at risk of their exclusion.

RESEARCH RESULTS: The analysis showed that the pandemic period significantly increased the need for individualized counseling support focused on the needs of youth at risk, taking into account the different contexts of their functioning.

CONCLUSIONS, INNOVATIONS, RECOMMENDATIONS: The aim of modern interventions in the field of lifelong guidance should not only prepare young people for finding a job, obtaining profession, completing education, but also developing or creating conditions for the development of career resources, which will prepare them for effective functioning on the labor market, and bringing them closer to complete, responsible maturity.

$\rightarrow$ KEYWORDS: YOUTH, EDUCATIONAL EXCLUSION, COUNSELLING SUPORT, NEET

\section{Wstęp}

Młodzi, młodzież to kategoria pojęciowa obecna od dawna w dyskursie nauk pedagogicznych, będąca przedmiotem i podmiotem licznych badań naukowych oraz interwencji pedagogiczno-wychowawczych. To także grupa społeczna, która w sposób szczególny doświadcza skutków pandemii COVID-19. Zmiany zaobserwowane wśród młodych w związku z pandemią dokonują się na różnych płaszczyznach, ale najczęściej identyfikuje się je w trzech obszarach. Pierwszy z nich związany jest z funkcjonowaniem młodych na rynku pracy, drugi ma związek z nauką, a trzeci odnosi się do zanikających interakcji społecznych (Mascherini i Campajola, 2020). Ze względu na sugerowaną objętość opracowania w artykule uwaga zostanie skupiona na obszarze związanym z aktywnością zawodową młodzieży. Celem opracowania jest wskazanie na potrzebę zaprojektowania 
wsparcia poradniczego dla młodzieży zagrożonej wykluczeniem edukacyjnym i społecznym, która znalazła się w trudnej sytuacji na rynku pracy.

\section{Sytuacja młodych na rynku pracy}

Analizując pozycję młodych na rynku pracy, widać, że ich sytuacja znacząco się pogorszyła i są oni nadreprezentowani w sektorach najbardziej dotkniętych restrykcjami. Według badania Eurofound 11\% respondentów w wieku 18-29 lat straciło pracę w czasie pandemii, w porównaniu z $8 \%$ pracowników powyżej 30. roku życia, a bezrobocie wśród młodzieży wzrosło od marca do września 2020 o 2,7\%, natomiast wśród osób dorosłych (powyżej 25 lat) wzrosło o 0,8\%. Ponadto młodzi częściej korzystają z nietypowych form pracy, co oznacza, że ich niepewność na rynku pracy jest większa niż w przypadku starszych grup wiekowych, dodatkowo $12 \%$ młodych postrzega siebie jako grupę, która może stracić pracę w ciągu najbliższych trzech miesięcy. Autorzy cytowanego opracowania przewidują, że liczne obostrzenia mogą jeszcze mocniej uderzyć w młodych i ograniczyć szanse ich zatrudnienia (Mascherini i Campajola, 2020). Pomimo tego, że Polska wciąż jest krajem z najniższym bezrobociem w Unii Europejskiej i drugim najniższym na świecie, to sytuacja młodych do 25. roku życia wygląda zupełnie inaczej. Ich stopa bezrobocia urosła w Polsce w ciągu roku o 5,2\%, to trzeci najszybszy przyrost w Unii Europejskiej (Hirsch, 2021). Obecnie najtrudniejsza sytuacja na rynku pracy dotyczy właśnie osób młodych, w tej grupie najszybciej wzrosło bezrobocie oraz poziom bierności zawodowej (Błaszczak, 2021). Fakt, że skutki kryzysu wywołanego COVID-19 najbardziej odczują właśnie osoby do 25. r.ż. (a także kobiety i pracownicy zatrudnieni w nisko płatnych zawodach) potwierdzają także wyniki badań Brytyjskiego Instytutu Badań Fiskalnych (IFS). Znaczny odsetek osób z tych grup jest zatrudniony w zamrożonych na czas pandemii branżach. Eksperci IFS podkreślają, że

(...) globalny kryzys spowodowany pandemią będzie miał długoterminowy wpływ na kariery zawodowe młodych przed 25 r.ż., co skłoniło Międzynarodową Organizację Pracy (ILO International Labour Organisation) do określenia tej grupy demograficznej mianem „Pokolenia Lockdown”. ILO w raporcie Monitor argumentuje, że COVID-19 będzie miał „niszczący i nieproporcjonalny" wpływ na perspektywy zawodowe młodych osób. Pokolenie osób poniżej 25. roku życia jest w obecnej sytuacji narażone na potrójny szok na rynku pracy (młodym częściej grozi utrata pracy niż reszcie ludności; istnieje większe prawdopodobieństwo doznania przez nich zakłóceń w edukacji lub szkoleniu zawodowym i w wyniku gorszej koniunktury napotkają na większe bariery przy wejściu na rynek pracy) (Szewczyk, 2020).

Przywołane dane oraz analizy rynkowe wydają się uprawniać do przyjęcia założenia, że w kontekście skutków pandemii młodzież, a szczególnie podkategorie młodych, które już wcześniej miały problemy z aktywnością zawodową, staje się grupą wymagającą wzmocnionego wsparcia poradniczego. 


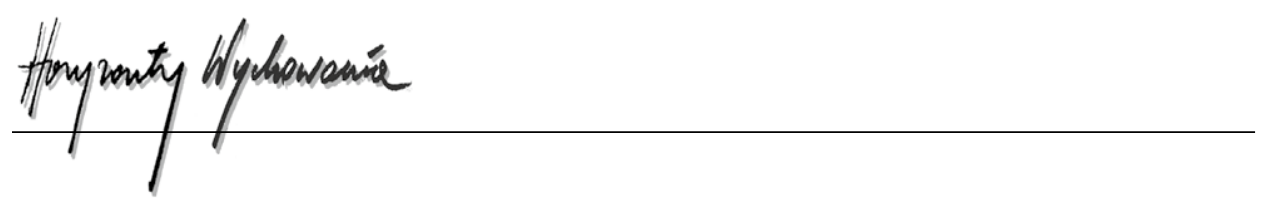

\section{Kategorie młodych zagrożone wykluczeniem}

Bierność i trudności z wejściem młodzieży na rynek pracy stają się problemem, który powoduje długoterminowe konsekwencje dla jednostek, grup społecznych oraz całych gospodarek. Warto zauważyć, że jest to zagadnienie od dawna obecne w przestrzeni publicznej, jednak w kontekście bieżących wydarzeń nabiera większego znaczenia i skłania do pogłębionej refleksji nad podgrupą młodych określaną mianem NEET (Not in Employment, Education and Training - grupa społeczna obejmująca młodzież pozostającą poza sferą zatrudnienia i edukacji) oraz problemami związanymi z młodzieżą wypadającą z systemu edukacyjnego bądź przedwcześnie opuszczającą edukację (ESL - Early School Leaving). Dlatego zasadne wydaje się przyjrzenie tym kategoriom młodych osób oraz uczynienie z nich grupy wymagającej wzmocnionego wsparcia poradniczego. Warto zauważyć, że pandemia, a wraz z nią nowe warunki życia, edukacji i pracy często przybierają postać niesprzyjających warunków rozwoju, czynników utrudniających aktywność edukacyjną bądź zawodową młodych, między innymi tych z kategorii NEET, ale zwracają także uwagę na osoby młode dotknięte wykluczeniem edukacyjnym. Przywołane kategorie mają ze sobą wiele wspólnego. Zdaniem AnneMarie Oomen oraz Petera Planta zjawisko przedwczesnego opuszczania edukacji (ESL) nie jest pojęciem stałym i w niektórych kontekstach jest ono używane zamiennie z innymi terminami: ELET (Early Leavers from Education and Training), interrupted learners, school dropouts oraz NEET. Cytowani autorzy podkreślają, że wspólną cechą wskazanych określeń jest fakt, iż koncentrują się na osiągnięciu pewnego poziomu edukacji szkolnej i nauki, co z kolei odzwierciedla ogólny pogląd, że potencjał młodzieży powinien być wykorzystywany i rozwijany poprzez naukę. Ponadto liczne dowody wskazują, że osoby przedwcześnie kończące naukę są bardziej narażone na bezrobocie i wykluczenie społeczne, co powoduje koszty finansowe i niefinansowe dla nich samych, a w dłuższej perspektywie czasowej także dla społeczeństwa (Oomen i Plant, 2014, s. 9). Informacje te wydają się szczególnie istotne w kontekście warunków społeczno-gospodarczych kształtowanych przez pandemię. Warto przypomnieć, że kategoria pojęciowa NEET postrzegana jest jako poważny problem Unii Europejskiej, generujący ogromne koszty społeczne już od przełomu pierwszej i drugiej dekady XXI wieku (Eurofound, b.d., s. 1-8). Tym samym trzeba podkreślić, że od tego czasu populacja NEET jest wskaźnikiem kształtującym zorientowane na młodzież polityki dotyczące zatrudnialności, edukacji, szkoleń, a także włączenia społecznego w państwach UE. Analizując kategorię NEET, warto dodać, że nigdy nie była i nadal nie jest ona populacją jednorodną, a najnowsze dane Eurofound wskazują aż siedem podgrup w obrębie NEET, co powinno pomóc w lepszym zrozumieniu sytuacji młodych oraz opracowaniu odpowiednich środków wsparcia, dostosowanych do potrzeb poszczególnych podkategorii (Eurofound, 2021). Warto zauważyć, że do NEET często przynależą osoby, które nigdy nie otrzymały właściwego wsparcia edukacyjnego czy zawodowego od najbliższego otoczenia, pozbawione były pozytywnego treningu dorosłości i są bardziej narażone na wykluczenie społeczne. Skutki pandemii natury społecznej i psychologicznej nie 
sprzyjają wyjściu z bierności, a dodatkowo często stają się czynnikiem zwiększającym ryzyko popadnięcia w nią. Potwierdzeniem tego zagrożenia jest zjawisko „wypadania” z systemu edukacyjnego, obserwowane również w Polsce. Obostrzenia pandemiczne, edukacja zdalna wskazują na narastający problem „ginących uczniów”. Ci, którzy „wypadli" z systemu, to uczniowie z rodzin zaniedbanych, niewydolnych wychowawczo, niemogących zapewnić im odpowiedniego wsparcia oraz dostępu do sieci. Prawdopodobnie są to uczniowie, którzy w przyszłości zasilą populację NEET. Pomimo doniesień medialnych wskazujących na nasilanie się problemu brakuje statystyk pokazujących skalę zjawiska oraz narzędzi, które skutecznie pozwalałyby zbierać tego typu dane. Z informacji Związku Nauczycielstwa Polskiego wynika, że „problem dotyczy niemal każdej szkoły i takich uczniów łącznie może być nawet ok. 50 tysięcy” (Szpunar, 2021, s. 4). Problem związany z wypadaniem uczniów z systemu stanowi nie tylko wstęp do przyszłej bierności zawodowej, ale jest także ściśle skorelowany z wykluczeniem edukacyjnym, które w przyszłości często przechodzi w wykluczenie społeczne. W tym miejscu warto wyjaśnić, że w sytuacji wykluczenia edukacyjnego dziecko nie realizuje swojego potencjału rozwojowego z przyczyn pozostających częściowo lub całkowicie poza jego wpływem. Dlatego wskazuje się na różnorodne przyczyny wykluczenia edukacyjnego (zdrowotne, środowiskowe, ekonomiczne, techniczne i inne) i podkreśla się, że wiele z nich często występuje jednocześnie lub jedne wywołują kolejne (Stokowska i Pieńkowski, 2021, s. 2-3). Są rodziny, w których spotykamy większość z tych problemów. Niestety „nie ma jednoznacznych środków zaradczych eliminujących poszczególne przyczyny, ale warto pamiętać, że próby ukierunkowane na eliminację choćby jednej z nich mogą przeciąć sekwencję niekorzystnych zdarzeń prowadzącą do porażki edukacyjnej i straconych szans" (Słowik, 2021, s. 3), a tym samym zapobiec przynależności do populacji NEET w przyszłości. Czynnikiem pogłębiającym problem wykluczenia edukacyjnego jest też sama edukacja zdalna, która według szacunków ekspertów Banku Światowego powoduje u uczniów takie luki, jakby z całego okresu edukacji wycięto im ponad semestr, pomimo tego że lekcje się odbywają (Słowik, 2021, s. 3). Sytuacji nie poprawiają też liczne absencje uczniów podczas edukacji zdalnej, które zwiększają ryzyko trwałego wykluczenia edukacyjnego (Stokawska i Pieńkowski, 2021, s. 9). Chociaż brakuje miarodajnych badań na temat skali zaległości, oczywisty jest fakt, że najwięcej stracili najmniej zdolni (Słowik, 2021, s. 3), co niestety prognozuje pogłębianie się problemów edukacyjnych tych uczniów i w konsekwencji przybliża ich do ewentualnej decyzji o porzuceniu bądź przedwczesnym ukończeniu nauki.

Lukę edukacyjną z dużym prawdopodobieństwem pogłębiają także różnice w kapitale kulturowym rodziców, którzy nie potrafią udzielić wsparcia swoim dzieciom. Przedwczesne kończenie nauki (ESL) jest kosztowne nie tylko dla jednostki, ale także dla społeczeństwa i gospodarki. Nie tylko w sensie ekonomicznym, ale również w sensie niskiej samooceny i ryzyka wykluczenia społecznego. Lepsze wykształcenie może prowadzić do pozytywnych rezultatów w odniesieniu do zatrudnienia, poziomu wynagrodzeń, lepszego zdrowia, mniejszej przestępczości, większej spójności społecznej, niższych kosztów publicznych i społecznych oraz wyższej wydajności. Również w tym kontekście 


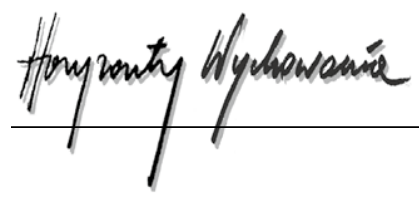

poradnictwo przez całe życie ma do odegrania kluczową rolę zarówno w zakresie zapobiegania, jak i strategii kompensacyjnych (Oomen i Plant, 2014, s. 7).

Warto wspomnieć, że zjawisko wypadania z edukacji nie jest nowe i zaznaczyło swoją obecność $w$ działaniach unijnych już przed laty ${ }^{1}$. Jednak pomimo zobowiązań nałożonych na państwa członkowskie UE w Polsce nadal brakuje efektywnego sytemu monitorującego liczbę „zagubionych” uczniów, co z kolei wyklucza skuteczność jakichkolwiek działań profilaktycznych oraz interwencji edukacyjnych wobec uczniów zagrożonych ESL. Biorąc pod uwagę brak narzędzi monitorujących problem „wypadania z systemu", warto dokładniej przyjrzeć się mechanizmom zwiększającym jego ryzyko. Według Oomen i Planta obok przyczyn bezpośrednio związanych z osobą porzucającą naukę są też takie, które odnoszą się do samego zjawiska wypadania z systemu (drop out vs push out - odrzucenie vs wypchnięcie z systemu) oraz systemu edukacyjnego i form uczenia się (schooling and learning: informal/non-formal/formal learning). Autorzy opracowania konkludują, że polityka oraz programy międzysektorowe mogą i powinny odgrywać dużą rolę w wysiłkach na rzecz zapobiegania przedwczesnemu kończeniu nauki przez młodych, a ESL trzeba rozumieć jako problem systemu edukacyjnego, społeczeństwa, a nie wyłącznie jako problem poszczególnych jednostek, spowodowany przez ucznia, jego rodzinę, pochodzenie czy rówieśników (Oomen i Plant, 2014, s. 11-12). Proponowany sposób widzenia problemów związanych z ESL zmienia optykę postrzegania osób doświadczających tych trudności. Wcześniej to osobę, a nie instytucję edukacyjną postrzegano jako problem, co znajdowało odzwierciedlenie w naznaczaniu osób nieuczestniczących w edukacji formalnej lub opuszczających instytucje edukacyjne. Cytowani autorzy podkreślają, że w przypadku osób, które wypadły z systemu (ESL) oraz NEET wspólną etykietą, jaką im przypinano, było „porzucenie nauki”, tymczasem cechą wspólną tych osób jest to, że niełatwo wpasowują się w główny nurt edukacji albo raczej że główny nurt edukacji nie odpowiada ich potrzebom (Oomen i Plant, 2014, s. 11-12). Zmiana optyki postrzegania problemu wskazuje na fakt, że osoby te mogą być raczej wypchnięte przez system, a nie system porzucające. Analizując nakreśloną sytuację, warto także zasygnalizować problem braku kompetencji cyfrowych osób odpowiedzialnych za realizację edukacji zdalnej (Skowron, 2020, s. 131), który w połączeniu z trudnościami z wpasowaniem się uczniów w główny nurt edukacji zwiększa ryzyko porzucenia bądź zawieszenia edukacji. Kolejny czynnik, na który zwraca się uwagę, to zależności, jakie funkcjonują w systemie edukacji pomiędzy instytucjami ten system budującymi, relacje między edukacją formalną a uczeniem się pozaformalnym i nieformalnym, co generuje potrzebę dokładniejszego zdefiniowania kategorii osób przedwcześnie opuszczających edukację, a jednocześnie podkreśla

${ }^{1}$ W czerwcu 2010 r. ministrowie edukacji państw UE uzgodnili ramy spójnej, kompleksowej i opartej na dowodach polityki przeciwdziałania przedwczesnemu kończeniu nauki, wówczas przyjęto zalecenie w sprawie polityki, mającej na celu ograniczenie zjawiska ESL (Oomen i Plant, 2014, s. 7). Jednym z celów strategii „Europa 2020” jest ograniczenie zjawiska przedwczesnego kończenia nauki do poziomu poniżej $10 \%$. 
ogromne znaczenie niestandardowych form edukacji, promując tym samym ideę uczenia się przez całe życie (Oomen i Plant, 2014, s. 11-12).

Prezentowane podejście podkreśla ogromne znaczenie czynników zewnętrznych, kształtujących bierność młodych, tym samym wskazuje na konieczność zaprojektowania dopasowanego wsparcia poradniczego, ukierunkowanego na aktywizację młodzieży zarówno w obszarze rynku pracy, jak i edukacji. Dodatkowo warto zaznaczyć, że w kontekście rozważań dotyczących systemu edukacyjnego największe znaczenie aktywizujące dla osób przedwcześnie kończących naukę mogą mieć nietradycyjne formy uczenia się. Co istotne, w niektórych państwach członkowskich omawiane kwestie są uwzględnione w przepisach prawa oświatowego. W Polsce od kilku lat Instytut Badań Edukacyjnych prowadzi intensywne działania związane ze Zintegrowanym Systemem oraz Rejestrem Kwalifikacji (ZSK, ZRK), które pomagają określić relacje między edukacją formalną, nieformalną i pozaformalną.

\section{Wsparcie poradnicze adresowane do młodych osób z grup szczególnego ryzyka}

Trudna sytuacja, w której znalazły się osoby młode, implikuje potrzebę wsparcia poradniczego, będącego poszerzeniem oferty doradczej realizowanej w ramach systemu edukacyjnego, gdyż osoby przynależące do kategorii NEET oraz ESL często pozbawione są dostępu do tego typu usług. O ile państwa członkowskie UE zapewniają swoim obywatelom kształcenie i poradnictwo zawodowe w ramach systemu edukacyjnego, problem pojawia się w przypadku młodzieży będącej poza nim. Warto nadmienić, że wyniki badań w obszarze poradnictwa całożyciowego sugerują, że może ono mieć wpływ na dłuższe zatrzymanie uczniów w szkołach, na ich osiągnięcia, zmianę pracy, karierę i sukces życiowy (Oomen i Plant, 2014, s. 18). Literatura wskazuje również na pozytywne korelacje między poradnictwem całożyciowym a zjawiskiem przedwczesnego opuszczania nauki. Dotyczy to zwłaszcza sytuacji, gdy poradnictwo jest praktykowane z młodymi uczniami i wdrażane w sposób systematyczny. Organizując wsparcie poradnicze dla młodzieży z grup szczególnego ryzyka, warto zastanowić się nad bardziej integrującym podejściem do nauki, koncentrować się na jednostkach i dostosowywać działania do ich potrzeb, uwzględniając przy tym różne konteksty, w których młodzi funkcjonują i dorastają. Działania z zakresu poradnictwa warto zorganizować w taki sposób, aby koncentrowały się także na zapewnieniu osobom objętym wsparciem możliwości uczenia się w celu rozwijania ich umiejętności oraz zdobywania kwalifikacji. Aby zrealizować cele poradnicze, warto zastosować różnorodne metody i podejścia w zakresie poradnictwa, zapewniające ciągłość i dostępność edukacji przy wykorzystaniu technologii informacyjno-komunikacyjnych, we współpracy z przeszkolonymi ekspertami w dziedzinie poradnictwa (Oomen i Plant, 2014, s. 18-19).

Organizując interwencje poradnicze, należy mieć na uwadze także fakt, że współcześnie następuje przejście od poradnictwa zawodowego, zorientowanego na dawanie instrukcji i ekspercką pomoc w wyborze profesji, do poradnictwa konstruowania kariery/ 


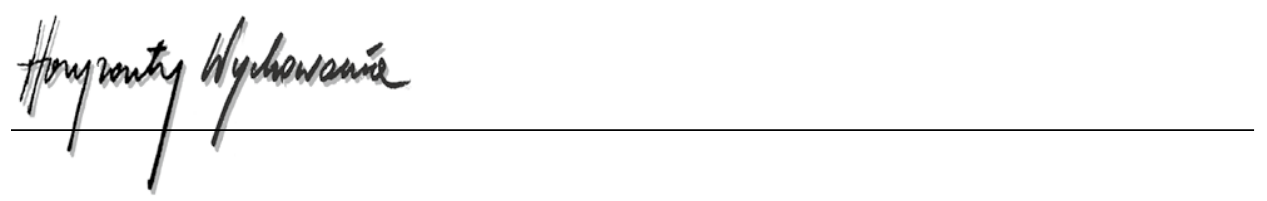

życia (Minta, 2012, s. 19). Zmiana sposobu uprawiania poradnictwa jest istotna również w kontekście młodych osób, które nie wpisują się w tradycyjne wzory przebiegu ścieżki edukacyjnej. W pracy z nimi warto odwołać się do poradnictwa konstruktywistycznego, narracyjnego, socjodynamicznego, gdzie rolą doradcy nie jest bycie ekspertem, ale towarzyszem w konstruowaniu własnej ścieżki kariery, w którym wzajemne relacje osób w nim uczestniczących za sprawą dialogu i zrozumienia nabierają szczególnego wymiaru. Przykładem dobrych praktyk w tym zakresie może być pilotażowy Projekt InnowacjiMałe Wielkie Zmiany „Praca szansą na dobry strat w dorosłość”, realizowany co prawda w warunkach przedpandemicznych, jednak zakładający działania poradnicze skierowane do młodych zagrożonych wykluczeniem bądź niedostosowaniem społecznym².

W procesie poradniczym dla osób zagrożonych wykluczeniem społecznym, u progu tranzycji z edukacji na rynek pracy, niezwykle ważne są także realizowane treści, dlatego warto podjąć tematy związane z funkcjonowaniem współczesnego rynku pracy, a w nich między innymi kwestie dotyczące tradycyjnego i elastycznego zatrudnienia, walidacji kwalifikacji, kompetencji, możliwości ich zdobywania, reputacji wirtualnej, instytucji wspierających młodych w wejściu na rynek pracy itp. Z kolei stosowane metody powinny zakładać elastyczne podejście do sesji poradniczych, powinny wzmacniać samodzielność i odpowiedzialność radzących się w podejmowaniu decyzji nie tylko zawodowych, ale również życiowych oraz sprzyjać realizacji głównego celu tych interwencji, czyli przywróceniu młodych do aktywności edukacyjnej i/lub zawodowej. Ważnym aspektem na etapie projektowania wsparcia poradniczego są także kwestie związane z kanałami dystrybucji tego wsparcia, autorka ma tutaj na myśli e-poradnictwo i rozszerzenie usług z zakresu poradnictwa za pomocą mediów społecznościowych bądź dedykowanych portali internetowych. Duńskie doświadczenia w tym zakresie pokazują, że czasami jest to jedyna droga, żeby dotrzeć do niektórych grup klientów (Himmelstrup, 2020). Praktykowane tam rozwiązanie wydaje się szczególnie korzystne dla tych, którzy wypadli z systemu, ale aktywnie funkcjonują w rzeczywistości wirtualnej. Potrzeba rozszerzenia kanałów dystrybucji usług poradniczych wyraźnie wybrzmiewa także w raporcie Lifelong guidance policy..., gdzie wskazuje się konieczność rozwoju otwartych, zintegrowanych strategii wraz z infrastrukturą wspierającą, niezbędną do opracowania i wdrożenia kompleksowych usług poradnictwa cyfrowego dla wszystkich obywateli w ciągu całego życia (Barnes i in., 2020, s. 64-72).

\section{Wnioski}

Podsumowując, warto podkreślić, że niniejszy artykuł stanowi jedynie próbę zarysowania problematyki związanej z trudnościami, na które narażona jest młodzież w obliczu

\footnotetext{
${ }^{2}$ Projekt kierowany był do byłych podopiecznych instytucji wychowania resocjalizacyjnego, którzy są zagrożeni niedostosowywaniem społecznym lub są niedostosowani po opuszczeniu placówki. Warunkiem wzięcia udziału w projekcie było ukończenie 18 lat oraz status osoby bezrobotnej.
} 
pandemii. Zasadniczym celem opracowania było zwrócenie uwagi na ryzyko wykluczenia edukacyjnego bądź bierności młodych, którzy doświadczają negatywnych skutków obecnej sytuacji społecznej oraz zasygnalizowanie palącej potrzeby zaprojektowania wsparcia poradniczego adresowanego do młodych przynależących do tzw. grup ryzyka. Warto przypomnieć, że w tym kontekście obie misje poradnictwa - zapobiegawcza (oferująca pomoc młodym ludziom w uniknięciu wykluczenia) oraz reintegracyjna (wspieranie osób obecnie wykluczonych w uzyskaniu dostępu do kształcenia/szkolenia i rynku pracy) - są jednakowo zasadne (Watts, 2001, s. 163). To od odpowiednio zaprojektowanego wsparcia poradniczego zależy przyszłość młodych osób dotkniętych pandemią. Poradnictwo odgrywa kluczową rolę w tworzeniu płynnych przejść, bardziej integracyjnego środowiska uczenia się, a także w tworzeniu usług wspierających oraz kolejnych szans edukacyjnych. Poradnictwo ma do odegrania dużą rolę zarówno we wspieraniu jednostek i grup w zakresie ESL oraz w zmianie samego systemu, który dopuszcza wykluczenie edukacyjne. Działania z zakresu poradnictwa warto zorganizować w taki sposób, aby koncentrowały się na jednostkach i dostosowywać działania do ich potrzeb, uwzględniając przy tym różne konteksty, w których młodzi funkcjonują. Skuteczne wspieranie indywidualnego rozwoju kariery i uczenia się można osiągnąć poprzez silniejszą synergię systemów, zapewnienie ściśle powiązanych ze sobą usług poradnictwa karierowego oraz określonych procedur walidacyjnych. Warto także pamiętać, że celem nowoczesnych interwencji w zakresie poradnictwa całożyciowego nie powinno być wyłącznie przygotowanie młodych do znalezienia pracy, zdobycia zawodu, uzupełnienia edukacji, reintegracji edukacyjno-zawodowej, ale także rozwinięcie albo stworzenie warunków do rozwoju zasobów karierowych, które nie tylko przygotują do efektywnego funkcjonowania na rynku pracy, ale też przybliżą ich do pełnej, dojrzałej, odpowiedzialnej dorosłości.

\section{BIBLIOGRAFIA}

Barnes, S.J., Bimrose, J., Brown, A., Kettunen, J. i Vuorinen, R. (2020). Lifelong guidance policy and practice in the EU: trends, challenges and opportunities. European Commission,

Błaszczak, A. (2021, 23 marca). Pandemiczny rynek pracy trudny dla młodych. Rzeczpospolita. https://www.rp.pl/Poszukiwanie-pracy/303239900-Pandemiczny-rynek-pracy-trudny-dla-mlodych.html

Eurofound. (b.d.). Young people and NEETs in Europe: First findings. https://movendi.ngo/wp-content/uploads/2015/03/NEET-and-youth-unemployment.pdf

Eurofound. (2021, 28 września). Młodzież NEET. Eurofound. https://www.eurofound.europa.eu/ $\mathrm{pl} /$ topic/neets

Himmelstrup, J. (2020, 15 lipca). The future of guidance is happening on Facebook. Ministry of Higher Education and Science. https://ufm.dk/en/education/internationalisation-and-cooperation/international-cooperation-on-guidance/euroguidance-denmark/publications-and-fact-sheets/the-future-of-guidance-is-happening-on-facebook/ the-future-of-guidance-is-happening-on-facebook 


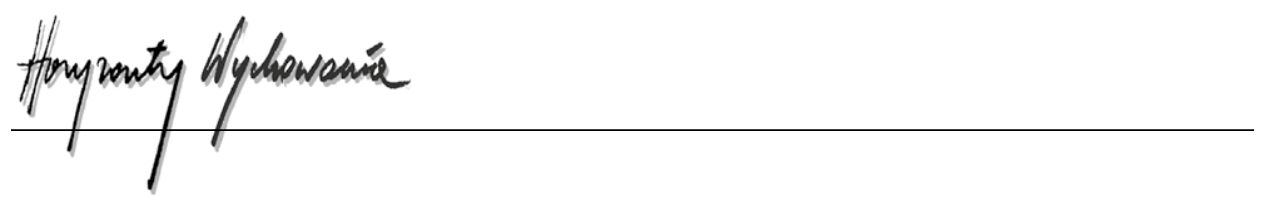

Hirsch, R. (2021, 7 kwietnia). Szybko rośnie bezrobocie młodych w Polsce. Business Insider. https://businessinsider.com.pl/piec-najwazniejszych-tematow-w-gospodarce-teraz-raport -7-kwietnia-2021/vg5309x

Mascherini, M. i Campajola, M. (2020, 23 października). Youth in a time of COVID. Eurofound. https://www.eurofound.europa.eu/pl/publications/blog/youth-in-a-time-of-covid

Minta, J. (2012). Od aktora do autora. Wspieranie młodzieży w konstruowaniu własnej kariery. Krajowy Ośrodek Wspierania Edukacji Zawodowej i Ustawicznej.

Oomen, A., Plant, P. (2014). Early school leaving and lifelong guidance. ELGPL Concept Note No. 6. http://www.elgpn.eu/publications/browse-by-language/english/elgpn-concept-note-no.-6 -early-school-leaving-and-lifelong-guidance/

Skowron, B. (2020). Zmaganie ze zdalną edukacją w akademii, szkole i przedszkolu. W: Nauczanie po pandemii. Nowe pytania czy nowe odpowiedzi na stare pytania? (s. 125-146). Instytut Problemów Współczesnej Cywilizacji im. Marka Dietricha.

Słowik, K. (2021). Dziura edukacyjna. Gazeta Wyborcza z 12.03.2021, dodatek Szkoła w pandemii.

Stokowska, A. i Pieńkowski, A. (red.). (2021). Jak przeciwdziałać wykluczeniu w edukacji? Fundacja Katalyst Education. https://power-ed.pl/dokumenty/Rekomendacje_PowerED_2021.pdf

Szewczyk, P. (2020, 9 czerwca). „Pokolenie Lockdown”, czyli nowe problemy młodych osób na rynku pracy. Deloitte. https://www2.deloitte.com/pl/pl/pages/press-releases/articles/Pokolenie-Lockdown-czyli-nowe-problemy-mlodych-osob-na-rynku-pracy.html?nc=1\&utm_campaign=IP_pokolenie_lockdown_C-RG-CON-06447_pl_2020_General_Email_pl\&utm_medium=email\&utm_ source=Eloqua

Szpunar, O. (2021). Szkoła pod respiratorem. Gazeta Wyborcza z 12.03.2021, dodatek Szkoła w pandemii.

Watts, A.G. (2001). Career guidance and social exclusion: a cautionary tale. British Journal of Guidance and Counselling, 29(2), 157-176.

\section{Copyright and License}

This article is published under the terms of the Creative Commons Attribution - NoDerivs (CC BY- ND 4.0) License http://creativecommons.org/licenses/by-nd/4.0/ 